\title{
Witkacego metafizyka cielesności
}

\author{
Maciej Dombrowski \\ Zakład Ontologii i Teorii Poznania \\ Uniwersytet Wrocławski \\ maciej.dombrowski[]uni.wroc.pl \\ Przyjęto: maj 2014; zaakceptowano: czerwiec 2014; opublikowano: lato 2014.
}

\section{Streszczenie}

Stanisław Ignacy Witkiewicz jest autorem specyficznej i oryginalnej metafizyki cielesności, którą rozwijał w drugiej połowie lat 30. Jako zwolennik realizmu i przeciwnik wszelkich odmian idealizmu, właśnie w ciele odnalazł Witkiewicz swoistą „gwarancję” realizmu. Zaproponował „poprawioną” wersję monadologii Leibniza, w której monady to już nie byty duchowe, ale psycho cielesne. Poczucie własnej cielesności stało się podstawowym doznaniem gruntującym realizm metafizyczny autora Szewców. Artykuł przedstawia główne wątki filozofii ciała Witkacego. Omówiona zostaje centralna kategoria „mojości”. Poruszona zostaje również kwestia stosunku ustaleń Witkacego do klasycznych, fenomenologicznych analiz cielesności zaproponowanych przez Husserla i Merleau-Ponty'ego.

Słowa kluczowe: Witkacy; ciało; metafizyka; fenomenologia; Husserl; Merleau-Ponty.

\section{Monadologia jako droga ku ciału. Witkiewicz a problem psychofizyczny}

Jestem $w$ pierwszej kolejności moim ciałem, moja jedność osobowości ma przede wszystkim charakter cielesny.

[S. I. Witkiewicz ${ }^{43}$ ]

Stanisław Ignacy Witkiewicz, bardziej znany jako artysta tworzący pod pseudonimem Witkacy, rozwijał w latach 20. i 30. XX wieku własny system filozoficzny nazwany przez niego „materialistyczną”, „realistyczną”, „biologiczną” lub, co istotne dla dalszych analiz, „cielesną” monadologią. Wraz z ustaleniami nauk - biologii i fizyki oraz tezami wynikającymi z tego, co można nazwać naturalnym nastawieniem czy też „poglądem potocznym” w nomenklaturze Witkacego - filozofia miała wejść w skład szerszego projektu określanego jako

\footnotetext{
${ }^{43}$ Wszystkie kolejne motta w artykule są autorstwa Witkiewicza.
} 
Ontologia Ogólna. Byłby to system wiedzy ostatecznej, ugruntowanej na ontologii jako wiedzy pierwotnej, a ustalenia nauk miałyby przy tym przejść proces „ontologizacji”, to znaczy zakorzenienia w rudymentarnych rozpoznaniach metafizycznych ${ }^{44}$.

Filozoficzna idée fixe Witkacego wydaje się co najmniej ekstrawagancka: cały byt, każdy jego składnik jest ożywiony i upsychiczniony (własności te wzajemnie się warunkują). Świat jest zatem zbiorem organizmów, które zostają nazwane monadami z racji swej wzajemnej odrębności. Monady są jedyną substancją, okazują się też całościami złożonymi (jednościami). W ich trwaniu można wyróżnić jakości odpowiedzialne za pojawienie się psychizmu (jaźni), czyli składniki bytu zależne od całości, w której występują (inaczej określone zostały jako „momenty niesamodzielne”). Takimi monadami są dla Witkacego także poczucie ciała i nadrzędna jakość spajająca pozostałe: „jedność osobowości”. Monada to inaczej „Istnienie Poszczególne” - na zewnątrz to organizm żywy, a postrzegana od środka jest „Bytem samym w sobie i dla siebie”.

Przy bliższym zapoznaniu się z propozycją Witkiewicza widać, że opiera się ona na odważnym eksperymencie myślowym. Witkacy każe nam zastanowić się nad ewentualnością obrania jako punktu wyjścia dla wiedzy o świecie biologii, a nie, jak to ma miejsce obecnie, fizyki. Otrzymujemy wtedy obraz inny od tego, do jakiego jesteśmy przyzwyczajeni, ale wedle przekonania autora Szewców - adekwatny i pozbawiony pułapek, jakie niesie ze sobą redukcyjny fizykalizm. Przede wszystkim taką pułapką jest nierozwiązywalność problemu psychofizycznego. Świadomość, jakości czy intencjonalność na gruncie skrajnego fizykalizmu redukcyjnego nie podlegają wyjaśnieniu, stanowią rodzaj epifenomenu, niepotrzebnego naddatku. Według Witkacego jedynym rozwiązaniem jest przyjęcie nieredukowalności i pierwotności tych własności. Skoro są one własnościami organizmów, należy przyjąć pierwotność również tych ostatnich. Tylko wtedy, zdaniem polskiego filozofa, problem psychofizyczny może zostać rozwiązany. Od razu pojawia się jednak konstatacja, że to, co proponuje Witkiewicz, stanowi w najlepszym razie jedynie zneutralizowanie problemu, na pewno nie jego rzeczywiste rozwiązanie. Wydaje się, że Witkacy ma rację, gdy twierdzi, że z materii ożywionej możemy na zasadzie statystyki („zasady wielkich liczb”) „otrzymać” materię martwą, gdyż ta ostatnia to po prostu nagromadzenie mikroskopijnych elementów tej pierwszej, ale natychmiast dostrzegamy, że proponowane „rozwiązanie” jest czysto iluzoryczne. Krytyk może zauważyć, że nadal grozi nam regres ad infinitum, zawsze bowiem aktualne pozostaje pytanie: $\mathrm{z}$ czego składają się same monady? Propozycja Witkacego opiera się zatem na paradoksie, próbie zbudowania systemu monistycznego (jedna, ożywiona substancja, monady to jedności) z jednoczesnym zaakcentowaniem wyjściowego i nieusuwalnego dualizmu

\footnotetext{
${ }^{44}$ Witkacy używa terminów „ontologia” i „metafizyka” zamiennie na oznaczenie podstawowej wiedzy o bycie. Nie respektuje zatem np. podziałów Ingardenowskich.
} 
(martwe/ożywione, ja/świat). Wyraźnie więc zbliża go ta postawa do poglądów starożytnych hylozoistów, przekonanych tak jak Witkiewicz, że życie, pierwotnie utożsamiane $\mathrm{z}$ ruchem, stanowi atrybut materii. Współcześnie podobne poglądy mogą, jak już wspomniałem, wydawać się w najlepszym wypadku ekstrawaganckie, w gorszym - szalone i niedorzeczne. Wbrew pozorom poglądy zbliżone do Witkiewiczowskich nie są aż tak rzadkie i dziś, pojawiają się na przykład w ramach filozofii umysłu, wystarczy tylko wspomnieć o dyskusji, jaką wzbudziła jakiś czas temu propozycja autorstwa Galena Strawsona (Strawson 2006; Freeman 2006), czy z najnowszych ujęć - ostatnia książka Thomasa Nagela (2012), autora, który już wcześniej zdradzał inklinacje w kierunku panpsychizmu.

Witkiewicz jako filozof wyraźnie biologizujący próbował znaleźć własne miejsce w przestrzeni współczesnych mu dyskusji. W filozofii biologii ramy debaty wyznaczały na początku XX wieku skrajne stanowiska mechanicyzmu i witalizmu. Między nimi plasowała się propozycja emergentystyczna, jawiąca się jako trzecia droga między Scyllą materializmu fizykalnego a Charybdą niematerialnych entelechii. Emergentyzm był jednak dla Witkacego poglądem, który można by określić jako „ukrytą opcję materialistyczną”; podobnie odnosił się on do idei dialektyki (Witkiewicz 2002a: 222). Życie jest albo go nie ma, nie istnieją jakieś stany pośrednie, stąd ataki Witkiewicza na koncepcję monizmu neutralnego Bertranda Russela czy też krytykowanie Leibniza, który głosił tezę o braku skoków w naturze, ciągłości przejść między własnościami. Inaczej mówiąc, obowiązywanie zasady wyłączonego środka w wypadku zagadnienia życia jest absolutne. Trzeba jednak podkreślić, że Witkacy nie był tu konsekwentny. Już wspomniana doktryna „momentów” zaciera nieco ostrość wyjściowej tezy. Wracam do tego wątku w dalszej części artykułu. Co ciekawe, również propozycja witalistów spotkała się z krytyką Witkacego - uznawał on, że jako filozof korzystający z ustaleń biologii i realista uprawia filozofię naukową nie musi uznawać za konieczne przyjęcia jakiejś wersji substancji duchowej, wręcz przeciwnie, jeśli już nawiązuje do witalizmu, to mówi, że w jego systemie mamy do czynienia z „ucieleśnioną, zmaterializowaną biologicznie entelechią” (Witkiewicz 2002b: 99). Nawet przychylny komentator zauważy, że etykieta materializmu bywa stosowana przez Witkacego bardzo wybiórczo, najczęściej tam, gdzie pozwala to na odcięcie się od domniemanego idealizmu. Istotnie, w kontekście na przykład myśli Leibniza, zasadne może być stosowanie dla systemu Witkiewicza określenia „materialistyczny”. Jest to jednak materializm bardzo specyficzny, w żadnym razie nie zbliża się do wersji fizykalistycznej. Na obronę Witkacego można tylko dodać, że samo pojęcie „materializm” trzeba uznać za nieostre; odmienne wersje tego stanowiska różnią się często zasadniczo. Z pewnością w ramach bardzo ogólnej definicji 
propozycja Witkiewicza daje się określić tym mianem ${ }^{45}$. Ponadto operuje on pojęciem „materii biologicznej”, która ma cechy odróżniające ją od materii rozumianej wąsko jako pewien substrat fizyczny.

W kontekście powyższych ustaleń widać, że stanowiska Witkacego w sporze o naturę rzeczywistości nie można łatwo ustalić. Z jednej strony jest to monizm (jest jedna substancja ożywiona lub inaczej: upsychiczniona), można wtedy określić je jako panpsychizm lub hylozoizm, z drugiej - monizm ten ma wymowę pluralistyczną, bo przyjmuje się w nim istnienie różnych gatunków monad (na wzór świata biologii). Ponadto byt jest zawsze wielością, na co wskazuje się już na początku budowy sytemu (Witkiewicz 2002b: 160) - ja jest zawsze różne od świata, który składa się z innych, choć podobnych do mnie bytów. Pluralizm ten ma swoje przedłużenie w strukturze samej monady, bo jest ona dualna, rozbita na sferę ciała (materii) i jaźni (jakości) ${ }^{46}$. Ostatecznie można w sporym uproszczeniu określić stanowisko Witkiewicza jako dualizm własności, w myśl którego materia i duch to atrybuty jednej substancji. Uproszczenie wynika z różnic, jakie zachodzą między różnymi wariantami tego stanowiska (teoria podwójnego aspektu, monizm neutralny) - dla Witkacego substancją jest obdarzona psychiką materia biologiczna, nie ma substancji bez tych własności istotnych (neutralnej).

Powyżej zarysowane stanowisko prowadzi do bardzo wielu problemów, z których dobrze zdawał sobie sprawę Witkacy. Sprowadzają się one do pytania, czy można zbudować spójny obraz rzeczywistości oparty na przeciwieństwach (Michalski 1979: 264). Odpowiedź na tak postawione pytanie jest trudna, sądzę jednak, że status quo między heteronomicznymi wątkami nie może być utrzymywane $\mathrm{w}$ nieskończoność i jedna $\mathrm{z}$ opcji ostatecznie bierze górę. W przypadku Witkiewicza monizujący aspekt jego filozofii okazał się silniejszy niż delikatna, dualistyczna homeostaza. Próbował ją utrzymywać na różne sposoby - na przykład przy pomocy stosowanej często formuły ,jedność w wielości” (Witkiewicz 1980: 92), której wariantem była doktryna niesamodzielnych momentów, czy przez uznanie pojęć „część” i „całość” za „pseudosprzeczne” (Michalski 1979: 264). Z analiz późnych prac filozoficznych Witkacego wyłania się wniosek, że to cielesność jest ostatecznie tym czynnikiem, który można uznać za konstytutywny dla scalającej heteronomiczne elementy wizji monady. Każda monada jako organizm posiada materialne, biologiczne ciało, stanowiące naturalną granicę każdego jednostkowego istnienia („Istnie-

\footnotetext{
${ }^{45}$ Taki „minimalny” materializm można scharakteryzować następująco: podstawowym składnikiem świata są byty rozciągłe, opisywalne $\mathrm{w}$ kategoriach czasoprzestrzennych, przyjmujemy naturalizm, uznajemy fizykę za naukę przynajmniej w pewnym stopniu adekwatnie ujmującą świat zewnętrzny.

${ }^{46}$ Koniec końców oba bieguny są wyrażalne w jakościach (choć innego rodzaju) - stanowi to rys psychologizmu, które to stanowisko mocno zaważyło na filozofii Witkacego i z którym cały czas dyskutował. Nawiązuję do tego w dalszej części tekstu.
} 
nia Poszczególnego”) oraz wyznacznik jej jedności. Doświadczenie własnej cielesności jest tym pierwotnym doznaniem, które - oczywiście w różnym stopniu - miałoby być udziałem wszystkich bytów.

Artykuł stanowi próbę rekonstrukcji i interpretacji wątków tego, co można by nazwać fenomenologią lub metafizyką cielesności, rozwijaną przez Witkacego $\mathrm{w}$ drugiej połowie lat 30 . XX wieku. Jest to jeden $\mathrm{z}$ mniej znanych wątków jego filozofii, nadal najczęściej kojarzonej z katastrofizmem lub koncepcjami estetycznymi. Wydaje się szczególnie ciekawy w odniesieniu do współczesnego zainteresowania cielesnością, zwłaszcza w kontekście badań nad poznaniem w ramach takich nurtów jak poznanie ucieleśnione, usytuowane, rozproszone czy enaktywizm. Poniżej ograniczam się jednak do perspektywy czasowej bliższej samemu Witkacemu, to znaczy omawiam jego koncepcję cielesności na tle dociekań fenomenologów zajmujących się statusem ciała.

\section{2. „Dotyk” jako gwarant realizmu albo Leibniz „poprawiony”}

Mój realizm zaczyna się od realności ciała, a fenomenalna realność rzeczy jest od niej pochodna.

Często podkreśla się, że ontologia Witkiewicza stanowi propozycję realistyczną, można jednak zastanowić się, dlaczego tak się dzieje, co okazuje się decydujące dla opowiedzenia się Witkacego po stronie metafizycznego realizmu? Czemu komponenta idealistyczna, którą stanowi opis monady „od środka”, jest jednak marginalizowana, gdy mowa o ogólnym wydźwięku systemu? Skąd zatem wiemy, że my sami oraz cokolwiek poza nami istnieje (realnie), dzięki czemu jesteśmy w stanie wyrwać się z „zaklętego kręgu przeżyć” (Witkiewicz 2002: 65) ${ }^{47}$ ? Odpowiedzi na te pytania można znaleźć na kartach pism Witkiewicza sukcesywnie ogłaszanych z rękopisów. W poniższych analizach najbardziej pomocny będzie Traktatu o Bycie samym $w$ sobie i dla siebie (Witkiewicz 2002a) ${ }^{48}$ oraz Spór o monadyzm (Witkiewicz 2002c). Istotnym źródłem wiedzy o omawianych zagadnieniach jest także korespondencja z dwoma filozofiami, przyjaciółmi Witkacego: Romanem Ingardenem (Witkiewicz, Ingarden 2002) i Hansem Corneliusem (Witkiewicz 1978, 1979, 1980).

\footnotetext{
${ }^{47}$ Monady od wewnątrz nie da się inaczej określić niż poprzez zestaw specyficznych, odczuwanych jakości. Perspektywa transcendentna jest dana nam również w postaci jakości. Właśnie ten stan rzeczy nazywa Witkacy „zaklętym kręgiem przeżyć” i uznaje komponentę idealistyczną każdego systemu za konieczną.

${ }^{48}$ Kwestie dotyczące tej pracy wymagają jednak wyjścia poza bibliografię i doprecyzowania. Przywołane w bibliografii wydanie, które cytuję, poprzedzone wstępem edytora - Bohdana Michalskiego (stąd tytuł całości opracowania, którego częścią jest praca Witkacego, w opisie bibliograficznym rozdzieliłem oba elementy), nie jest edycją pełną Traktatu, pominięto $\mathrm{w}$ niej dwa ważne dodatki. Całość, przygotowana przeze mnie do druku, ukaże się w kolejnym tomie Pism Zebranych Stanisława Ignacego Witkiewicza, który jest już złożony w Państwowym Instytucie Wydawniczym.
} 
W pierwszej z przywołanych prac Witkiewicz bardzo wyraźnie opowiada się za dotykiem jako konstytutywnym i niezbywalnym dla monady, czyli właśnie „Bytu samego w sobie i dla siebie”: ,[...] bez jakości dotyku zewnętrznego i wewnętrznego jest on nie-do-pomyślenia” (2002a: 230). Pozostałe jakości są pewnym „naddatkiem” i Witkacy określa je stosownie jako „zbytkowe” lub „luksusowe”. Okazuje się, że tym, co ratuje nas przed byciem wyłącznie leibniziańską „monadą bez okien”, jest jeden ze zmysłów - właśnie dotyk. To dzięki niemu uzyskujemy pewność - w pierwszej kolejności - istnienia nas samych, a dalej innych bytów rozciągłych. Przywołanie jednego ze zmysłów i określenie go jako właściwie jedynego gwaranta realności jest zabiegiem bardzo problematycznym.

Witkiewicz przyznaje, że definiowanie realności poprzez odwołanie się do instancji dotyku jest „pseudodefinicją" (2002a: 236), a to z tej przyczyny, że o tym, czym właściwie ma być owa realność, nic się tu nie mówi, jednocześnie de facto posługując się tym terminem. Witkiewicz zdaje sobie dobrze sprawę, że nie będzie w stanie rozwiązać zadowalająco problemu realności - stwierdza nawet, że „w pewnym [...] sensie wszystko jako takie jest realne, wszystko, co jakoś istnieje” (2002a: 236). Nie ma zatem ścisłej definicji realności można raczej powiedzieć, że „byt jest”, gdzie dodanie predykatu „realny” niczego nie dookreśla. Pytanie o samą realność, niejako oddzielanie jej od przedmiotu - bytu - okazuje się zabiegiem bezcelowym. Określenie czegoś jako realnego nie „dodaje” nic do jego definicyjnej charakterystyki, jako że Witkacy odrzuca istnienie jakichkolwiek bytów idealnych. Z powyższego wynika, że byt dla Witkiewicza jest zawsze dany przede wszystkim „dla siebie”, podstawę stanowi samoczujące się i doznające bodźców ciało. Stąd wyróżniony status ja - Istnienia Poszczególnego, będącego właśnie „wzorcowym” „Bytem dla siebie".

Problemu realności Witkiewicz nie może jednak pominąć - ontologia monadyzmu biologicznego ma być propozycją realistyczną - świat jest wielością obdarzonych samoświadomością organizmów. Jak twierdzi filozof: „Musimy przyjąć coś jako realność pierwszą, niesprowadzalną, o ile w ogóle pojęcie realności jako pierwotne wprowadzić mamy. Definicja realności w terminach (XN) dotyku jest, według mnie, pseudodefinicją zawierającą już przedmiot definiowany, tym niemniej jest jedyną [...]"49 (Witkiewicz 2002a: 236). Realność, jako pewna pierwotna własność bytu, sprowadza się zatem do dotyku cechującego ciało ożywionej monady, stąd jej sygnalizowana już kolistość. Inaczej mówiąc, pytanie o realność bytu jest zawsze samozwrotne, odwraca wektor ze świata znów w kierunku podmiotu, który je zadaje, możliwa definicja polega zawsze na wskazaniu samego siebie i nam podobnych istot (Witkiewicz 79: 151). Witkiewicz, aby ugruntować realność ciała, określa ją jako

\footnotetext{
${ }^{49}(\mathrm{XN})$ to w zapisie Witkacego symbol jakości.
} 
„absolutną”, „pierwszą i jedyną”, podczas gdy realność cechującą inne przedmioty nazywa jedynie „fenomenalną” i „zjawiskową”50 (Witkiewicz 1980: 94, 97, 2002a: 239, 2002c: 35, 95). Błąd wszystkich idealistów polega - zdaniem autora Zagadnienia psychofizycznego - na absolutyzowaniu ostatniego z typów realności, na uznaniu, że świat, a zatem i my sami, jest jedynie przedmiotemfenomenem. Podsumowując, choć Witkacy nie podaje definicji realności, proponuje coś, co można nazwać „realnością przez dotyk”; sam mówi o dotyku jako o „kryterium” rzeczywistości (Witkiewicz 2002a: 237). Od poczucia własnego ciała poprzez czucie innych ciał wiedzie, według autora Traktatu o Bycie..., droga do uznania świata w jego pełnej, to jest intersubiektywnej realności.

Dotyk jest zmysłem najważniejszym ze względu na to, że to właśnie dzięki niemu przekonujemy się o istnieniu ciała - zdaniem Witkacego człowiek całkowicie pozbawiony czucia w obrębie zarówno organów wewnętrznych, jak i powierzchni skóry, miałby duże powody do obaw co do własnej realnej egzystencji. Witkacy odwołuje się nawet do Biblii: „,...] to jest rzeczywiste, co jest dotykalne, namacalne; św. Tomasz miał rację, gdy uwierzył w ranę Chrystusa, wsadziwszy w nią palec [...]” (2002a: 237). Można powiedzieć, że dla Witkiewicza każdy jest „niewiernym Tomaszem”, który musi czegoś dotknąć, by uznać to za realnie istniejące. Od razu można zadać pytanie o szczególne przypadki ludzi sparaliżowanych lub nękanych bólami fantomowymi. Witkacy nie zajmuje się tym problemem, ale najpewniej interesuje go przypadek przeciętny, a nie wyjątkowe sytuacje jak te wspomniane wyżej. Podobnie jak daltonizm można by uznać za dysfunkcję układu nerwowego, bez konieczności wyciągania daleko idących wniosków. Nie jest to z pewnością odpowiedź satysfakcjonująca filozoficznie, ale można domniemywać, że takiej udzieliłby Witkacy.

W przytaczanych ustaleniach zawiera się to, co nazwać można „poprawieniem” filozofii Leibniza, którego - jak się przyjmuje - dokonać miał Witka$\mathrm{cy}^{51}$. Monady mają więc „okna”, mogą kontaktować się ze sobą, „oknem” każdej monady jest jej ciało - rozciągłe i w pełni realne. Status ciała u samego Leibniza nie jest jednak tak oczywisty, jak to ma miejsce w obiegowej interpretacji jego filozofii, gdzie kładzie się nacisk na obraz świata jako złożonego z duchowych, niematerialnych monad podporządkowanych monadzie najwyższej - Bogu. Monady u Leibniza mają cielesność, ale podporządkowaną duszy. Dusze to dla niemieckiego filozofa dziedzina praw celowych (teleologia), ciała - dziedzina przyczyn sprawczych (prawa ruchu). Harmonię między

\footnotetext{
${ }^{50}$ Tu Witkacy odróżnia „realną fenomenalność” rzeczywistych bytów w przestrzeni od „absolutnej fenomenalności”, która ma charakteryzować halucynacje.

${ }^{51}$ Związki między Witkiewiczem a Leibnizem omówił w swoim artykule Marek Rosiak (1988). Autor stwierdza jednak, iż „,...] ontologia Witkacego nie jest «poprawieniem» monadologii Leibniza, lecz jej dokonaną u samych podstaw rewizją” (Rosiak 1988: 63).
} 
tymi sferami gwarantuje Bóg dzięki „wprzód ustanowionej harmonii” (Leibniz 1995: 127). Związek pomiędzy ciałem a duchem nie jest zatem określany na poziomie samej monady, ale jest realizowany na poziomie transcendentnym - boskim. Choć więc - jak mówi Leibniz ,,[...] nie ma dusz całkiem oddzielonych ani też duchów pozbawionych ciała. Jeden tylko Bóg jest całkowicie odeń odłączony" (1995: 126), to jedność psychocielesna u autora Teodycei różni się zasadniczo od tej proponowanej przez Witkiewicza. Ten ostatni pojmuje monadę jako bardziej materialną, cielesną i przestrzennie ograniczoną. Monadologia Leibniza pozostaje propozycją idealistyczną. Jeśli mowa o realności monad u Leibniza, to jej gwarantem ma być ich jedność jako substancji - są to jednak zawsze substancje duchowe i, co ważne, nierozciągłe oraz niezłożone, co jest zupełnie przeciwne twierdzeniom Witkacego (por. Gut 2004: 98-99). W tych punktach Witkiewicz pozostał nieprzejednany; co do innych poglądów niemieckiego monadologia: dynamizmu, „monad śpiących” (pozbawionych apercepcji) oraz nieskończenie małych przejść między własnościami bytu - sprawa wygląda nieco inaczej.

Życie pojawia się nagle i nie jest nigdy sprowadzalne do czegoś martwego jest to punkt węzłowy filozofii Witkacego. Powstanie życia, racja jego zaistnienia na zawsze pozostanie dla niego tajemnicą. $\mathrm{Z}$ biegiem czasu stanowisko Witkiewicza ulega jednak złagodzeniu, granica między ożywionym i martwym nie rysuje się tak ostro. Już na początku lat 30. zaznaczał, że w samym bycie dają się wyróżnić różne stopnie „ożywienia”, które określamy przez stopień zaawansowania psychiki cechującej dany organizm. Witkacy używał w tym kontekście terminu „jedność osobowości”, oznaczającego stopień zintegrowania danej psychiki, która pierwotnie jest tylko luźnym związkiem jakości ${ }^{52}$. W późnej fazie swoich poglądów Witkacy wprowadza dodatkowo „doktrynę skal świadomości”, która zero-jedynkowy obraz bytu żywego lub martwego mocno komplikuje. Nie ma skali absolutnej, są różne skale przyporządkowane różnym organizmom. Skala ludzka ma się nijak do skali pierwotniaka, nasza psychika może być w swoim natężeniu równa stanowi uśpienia jakiegoś hipotetycznego, wyżej rozwiniętego bytu ${ }^{53}$. Brak już tak wyraźnego sprzeciwu wobec ustaleń Leibniza, wręcz przeciwnie, Witkacy zaczyna je akceptować. Godzi się też na doktrynę „monad śpiących”, które wykazują jedynie rudymenty psychiki. Nie ma już konieczności przyjmowania wielości jakości i jedności osobowości, a nawet wspomnień, które wcześniej nadawały ciągłość istnieniu (jeszcze w tekście głównym Traktatu o Bycie... wspomnienia są konieczne dla zachowania ciągłości istnienia). Do uznania monady za ożywioną wystarczy jedynie specyficzne „tło”. Jest ono pewnym „stanem ciała”,

\footnotetext{
${ }^{52}$ Witkacy stara się unikać terminu „świadomość” (Witkiewicz 2002: 61), który według niego jest pomostem prowadzącym do uznania „ducha” za samodzielną substancję.

${ }^{53}$ Nie ma więc mowy o niebezpieczeństwie tego, że monady to „człowiek w skali mikro”, czego obawia się Józef Tarnowski (2001: 34).
} 
jego śladowym poczuciem. Ewolucja świadomości, w wyniku której pojawia się pamięć, wyobrażenia, bardziej skomplikowane stany umysłowe - to wszystko oddala nas od stanu pierwotnego. Jak zaznacza Witkacy: „te [...] treści usuwają pierwotnie jedyną treść jedności osobowości, tj. ciało w tło zmięszane [...]" (Witkiewicz, Ingarden 2002: 52). Świadomość zostaje tu zredukowana do świadomości ciała, jest pozbawiona przepływu jakości i wspomnień. Wcześniej Witkiewicz przyjmował „tło” jako pewien „podkład” jakości obecnych w trwaniu aktualnym, w danej chwili przeżywanych, wyróżnionych nie odgrywało ono tak konstytutywnej roli. Następuje więc pewne odwrócenie porządku: to, co było zależne od przeżyć i w pełni ukształtowanej psychiki, staje się czymś podstawowym i najważniejszym: „[...] to tło wyrasta tu do czegoś nadrzędnego, co może istnieć samo dla siebie bez jedności i przeżycia jako takich, tj. ostro zarysowanych na nim: będzie to stan organizmu uśpionego, ta świadomość słaba, która dla nas w naszej skali jest niebytem” (Witkiewicz, w druku). Wszystkie wspomniane korekty poglądów są związane ze stopniowym dowartościowywaniem roli ciała i ograniczaniem wpływów psychologizmu, który dobrze służył do opisu rozwiniętej psychiki, zawodzi jednak w przypadku bardziej prymitywnych organizmów.

\section{3. „Mojość”, czyli „,ciało własne” u Witkiewicza}

Ciało posiada „mojość” (Meiningkeit - mój rodzony termin), której inne przedmioty nie mają.

Witkiewicz przyjmuje, że granica pomiędzy „,ja” a „innym” jest wyznaczalna to bariera naszego ciała ukonstytuowana obecnością ,jakości dwoistej granicznej”, określa ona nasze miejsce w przestrzeni i pozwala jednocześnie na kontakt z innymi bytami, które właśnie dzięki temu percypujemy jako zasadniczo inne od nas samych (Witkiewicz 2002a: 226). Autor Traktatu o Bycie... w tym punkcie rozważań precyzuje dotyk, o jakim mówi, wyróżnia bowiem jego dwa podstawowe rodzaje: pierwszy sprowadza się do poczucia materialności organów wewnętrznych ciała, drugi to „dotyk zewnętrzny (graniczny)”, dzięki któremu odczuwamy, jako nieprzekraczalną, granicę między własnym ciałem a innymi przedmiotami. Dotyk wewnętrzny warunkuje oczywiście swój skierowany na powierzchnię ciała i inne przedmioty odpowiednik, ale jest od niego „słabszy”, mniej określony - nie czujemy nigdy dokładnych granic i kształtu wątroby lub żołądka - poza stanami chorobowymi odczuwamy tylko bardzo słabo zarysowaną obecność tych narządów.

Takie pierwotne rozróżnienie okazuje się podstawą dla zaistnienia tego, co nazywamy rzeczywistością, pociąga ono za sobą twierdzenie o realności bytów, które się na nią składają - to znaczy twierdzimy, że oprócz naszego, „immanentnego” wnętrza jest jeszcze świat zewnętrzny, który nie może być w żadnym wypadku tożsamy z nami, gdyż byt jawi się zawsze jako „ograni- 
czony” i „odgraniczony” (Witkiewicz 1980: 97). Każde istnienie jest więc „samo w sobie”. Witkacy dodaje tu człon „i dla siebie”, co nie może zostać uznane za tak oczywiste, jak uważał. Każdy byt jest „dla siebie”, gdyż ma poczucie własnego istnienia, rzeczywistość zewnętrzna może mu być dana tylko fenomenalnie. Paradoks polega na tym, że dla Witkacego każde istnienie to istnienie „dla siebie”, co wynika z tezy o panpsychizmie bytu. W tym punkcie jego stanowisko przypomina filozofię Berkeleya, tyle że bez przyjęcia Boga; każda monada, dokonując ciągłej „samoobserwacji”, utrzymuje własne istnienie w jego pełni; nigdy nie będzie ono tylko fenomenalne. Stąd też oponuje Witkacy przeciw ogólnemu pojęciu przedmiotu. Jak pisze do Ingardena: nie ma przedmiotu, jest zawsze dane Dasein (Witkiewicz, Ingarden 2002: 34).

Podstawą istnienia monady pozostaje jednak „kompleks czuć cielesnych” (Witkiewicz 2002a: 227), który stanowi rudymenty odczuwania, to on okazuje się podstawą poczucia własnej osobowości, czyli ,,jedności osobowości” i tego, co Witkacy określa nowotworem słownym „mojość” (Witkiewicz 2002a: 225, Witkiewicz, Ingarden 2002: 63, Witkiewicz 2002c:34). „Mojość” jest „[...] specjalnym wypadkiem (pierwotnym, zasadniczym) rzeczywistej tożsamości w Istnieniu” (Witkiewicz 2002c: 342).

Tak więc od pierwotnego doświadczenia, jakim jest dla autora dotyk (a właściwie różne „dotyki”), dochodzi on, jak mogliśmy się przekonać, do swej koncepcji metafizycznej. Początku filozofii i metody dochodzenia do prawdy nie należy w takim razie szukać w tym, co poza nami, ani w czystej spekulacji, ale w obserwacji własnego organizmu, czyli w introspekcji. W tym miejscu ulega wyostrzeniu wyraźny rys antropocentryczny filozofii Witkacego, który uznaje, iż świat jest nam zawsze dany $\mathrm{w}$ perspektywie nieusuwalnie pierwszoosobowej, jesteśmy poddani ruchowi odśrodkowemu, wektor poznania i wszelkich działań biegnie zasadniczo od podmiotu do przedmiotu. Witkiewicz twierdzi, że: ,[...] musimy uznać nas samych jako jedyny istotnie wylegitymowany punkt wyjścia dla opisu świata i nas w tym świecie, a wszelkie inne opisy opisać właśnie w funkcji tego naszego indywidualno-odśrodkowego na Istnienie spojrzenia” (Witkiewicz 2002a: 234). Nie chodzi tu jednak o skrajny subiektywizm czy relatywizację - choć Witkacy wspomina o „obiektywności świata” jako „[...] niezupełnie dokładnej z powodu różnych punktów widzenia dla każdego osobnika zlokalizowanego w ściśle zlokalizowanym miejscu [...]" (Witkiewicz 2002a: 225) $^{54}$. Witkiewicz kładzie bowiem nacisk na twierdzenie, iż jedynym bytem, o którym możemy wypowiadać się adekwatnie, jesteśmy tak naprawdę tylko my sami i właśnie taka jak my jednostka psychofizyczna może stać się jedynym wyobrażalnym „,analogonem”, „wzorem” dla każdego innego istnienia. Z jednej strony ciało oddziela nas od innych bytów, z drugiej staje się pomostem do nich - są to $\mathrm{w}$ jakimś stopniu „pochodne tej pierwszej

\footnotetext{
${ }^{54}$ Jeśli mówić o neokantyzmie Witkiewicza, to raczej w wersji słabej komponenty charakterystycznej dla realizmu krytycznego.
} 
rzeczy” (Witkiewicz 1980: 102), nie mają „mojości”, ale dzielą z nami niektóre jakości: „rozszerzanie się, nieprzenikliwość i wagę” (Witkiewicz 1980: 97). Właśnie dzięki ciału posiadamy specjalną władzę poznawczą, którą Witkiewicz nazywa „wyobraźnią dotykową” - pozwala ona na nadawanie naszym postrzeżeniom waloru przestrzenności (2002c: 112).

Dla Witkacego najważniejsze jest „moje ciało”, ten „fizyczny przedmiot”, o którym mogę powiedzieć, jak o żadnym innym, ,ja”. Witkiewicz wszystkie te elementy określa jako „mojość”:

[...] po odrzuceniu świata zewnętrznego poza granice ciała, wyodrębnia się specjalnie ciało, na razie przez swoją „mojość”, która jest „mojością” wszystkich składających je czuć dotyku wewnętrznego i graniczno-zewnętrznego, związanych ze sobą $\mathrm{w}$ pewną organiczną i zorganizowaną (do działań) jedność, utrzymującą się w swej „mojości” i związanej z nią identyczności przez trwanie (AT) mimo przerw tego ostatniego (2002a: 238) ${ }^{55}$.

To właśnie stwierdzenie tego, co można by nazwać „,autotożsamością”, jest pierwotnym doświadczeniem cechującym organizm żywy, czyli - dla Witkacego - po prostu byt. Nasze ciało „,...] wyodrębnia się dla nas samych spośród wszystkich naszych przeżyć w sposób zupełnie specyficzny i nie znajdujący żadnej analogii w przedmiotach świata dookolnego [...]" (Witkiewicz 2002a: 234). Owo „wyodrębnienie” dokonuje się właśnie poprzez czucie podzielone na zewnętrzne i wewnętrzne. Pierwsze konstytuuje świat, drugie - nas samych. „Mojość” okazuje się więc funkcją dotyku.

Powyższe tezy przywodzą od razu na myśl całą tradycję fenomenologii ciała zarówno w nurcie związanym z Edmundem Husserlem, jak i z bogatą myślą francuską na czele z Merleau-Pontym. Przytaczane fragmenty pism polskiego autora brzmią wręcz jak kalki z prac autora Fenomenologii percepcji. Jest to o tyle ciekawe, że Witkacy nie mógł znać prac francuskiego fenomenologa, które powstały później. Trudno jednak zaprzeczyć, że rozważania Ponty’ego o „,ciele własnym” pasują tu idealnie, świetnie określając intencje Witkacego. Zastanawiające i ciekawe wydaje się to, że właśnie w Traktacie o Bycie... a jak zauważa jego wydawca, Bohdan Michalski, jest on „najobszerniejszą «krytyką husserlizmu»" (Michalski 2002: 223) - Witkacy porusza tak obszernie tematy bliskie temu, czym zajmowali się później sami fenomenologowie - nie tylko przecież autor Fenomenologii percepcji (Merleau-Ponty 2001), ale i sam Husserl w Medytacjach kartezjańskich $(1982)^{56}$ i wydanych wiele lat później

\footnotetext{
${ }^{55}$ Skrót (AT) oznacza u Witkiewicza jedność osobowości.

${ }^{56} \mathrm{~W}$ jednym $\mathrm{z}$ listów do Ingardena Witkacy wyraża chęć zapoznania się z tą pracą, nie wiadomo jednak, czy mu się to udało (Witkiewicz, Ingarden 2002: 49). Medytacje kartezjańskie są poświęcone ustaleniom odnoszącym się do kwestii intersubiektywności: istnienia innych podmiotów, choć samo zagadnienie ciała pojawia się tam już z całą mocą. Niektórzy badacze wskazują na jeszcze wcześniejszą pracę jako dowód zainteresowania ciałem u Husserla (Pokropski 2011: 120) - mowa o wykładach z roku 1907, które ukazały się drukiem dopiero w 1973 roku (Husserl 1991).
} 
Ideach fenomenologii i fenomenologicznej filozofii. Księdze drugiej (1974) ${ }^{57}$. Na ironię zakrawa fakt, że Witkiewicz krytykował współczesną mu fenomenologię właśnie za pominięcie problematyki ciała i w tym widział jej słabość.

\section{Witkiewicz a fenomenologia cielesności}

Nie ma świadomości, która obserwuje ciało, tylko jest świadome ciało, które ma wspomnienia, wyobrażenia i myśli.

W listach do Ingardena znajdujemy liczne żartobliwe uwagi Witkacego odnoszące się do problemu rzekomego zapoznania ciała w filozofii Husserla: „,...] (Husserl to dla mnie: oczy, okulary i broda bez ciała)" (Witkiewicz, Ingarden 2002: 32), „[...] ciało jest u podstawy, a Husserl nie ma ciała [...]”(Witkiewicz, Ingarden 2002: 56), ,Ja ciała Husserla nigdzie dotąd w jego pismach nie spotkałem - tylko oczy, okulary i brodę, powiewającą w intencjonalnej wichurze [...]” (Witkiewicz, Ingarden 2002: 71), „Ja nie twierdzę, że H[Husserl] nie mówi całkiem o ciele - nie mówi jako o czymś specyficznym i realnym, a jako korelacie w stosunku do jaźni transcendentnym" (Witkiewicz, Ingarden 2002: 74).

Można od razu zaznaczyć, że Husserl nadrobił „,braki”, jakie mu wytykał Witkiewicz - zagadnienie ciała ludzkiego zostało przez niemieckiego fenomenologa zbadane w przywołanych już, obszernych pracach. Szczególnie w drugiej części Idei (Husserl: 1974) pojawią się liczne uwagi i całe akapity, które okazują się bardzo bliskie ustaleniom Witkacego. Tak jest chociażby w $§ 37$. Części II zatytułowanym Różnice pomiędzy dziedzina wzrokową a dotykową, gdzie Husserl opowiada się za ,[...] uprzywilejowaniem lokalizacji wrażeń dotykowych [...]” - jak pisze dalej: „,Każda rzecz, którą widzimy, jest dotykalną rzeczą i jako taka wskazuje na bezpośredni związek z ciałem, ale nie dzięki swej widzialności” (Husserl 1974: 213). Znamienne jest ponadto odróżnienie bryły cielesnej Körper od ciała ożywionego - Leib (zob. Drwęga 2002: 80-82). Ciało ożywione, które jest jednocześnie odbierane jako własne, objawia się poprzez różnego rodzaju dotyki - to one je konstytuują. Ciało to, w przeciwieństwie do statycznego Körper, wykazuje swoistą dynamikę, przeobraża się, staje się w każdym momencie niejako na nowo.

Wydaje się jednak, że propozycję Husserla uznałby Witkacy za rozwiązanie pozorne - śledząc wywody autora Logiki transcendentalnej, trudno nie ulec wrażeniu, że cała ciekawa i wnikliwa analiza ciała jest tylko „kamuflażem” kryjącym ten sam, co dawniej, system idealistyczny. W ostatniej, III części Idei II zatytułowanej Konstytucja świata duchowego Husserl powraca do - tak przecież atakowanej przez Witkacego - dominacji sfery ducha, ponadto psy-

\footnotetext{
${ }^{57}$ Rozprawa ta jest oparta na pierwotnym manuskrypcie z 1912 roku opracowywanym do 1928 roku.
} 
chika nie jest dla Husserla czymś rozciągłym ${ }^{58}$. Jak pisze Andrzej Półtawski, komentując analizy Idei II, „Ostatecznie zatem traktuje Husserl wszelką rzeczywistość jako ukonstytuowaną w świecie ducha, utożsamionym ze światem czystej świadomości” (Półtawski 1973: 303) ${ }^{59}$.

Propozycja innego fenomenologa, wielkiego następcy Husserla, jakim był Maurice Merleau-Ponty, mogłaby - jak sądzę - spotkać się z większą aprobatą autora Traktatu o Bycie... U francuskiego filozofa znajdujemy również, oprócz bogatych analiz fenomenu ożywionego „ciała własnego”, fundamentalne przekonanie o równorzędności pierwiastka duchowego i cielesnego oraz wyraźny rys antyredukcjonizmu i antyesencjalizmu. Jest to postawa inna niż u niemieckiego filozofa, u którego „To Ja, resp. dusza, «posiada» ciało [...]” (Husserl 1974: 222) ${ }^{60}$ i bliska poglądom samego Witkacego. Wydaje się, że Merleau-Ponty w dowartościowaniu ciała idzie nawet dalej niż Witkacy, który koniec końców wierzył w obiektywność pojęć i widział szansę zbudowania ostatecznego systemu ontologii. Status ciała i złożoność naszego bycia w świecie, opisane przez francuskiego fenomenologa, nie dają nadziei na tak daleko posunięty optymizm poznawczy. Witkiewicz nie miał okazji sam ustosunkować się do analiz cielesności przeprowadzonych przez fenomenologów i choć należy domniemywać, że nie uznałby ich za $\mathrm{w}$ pełni zadowalające, to z pewnością wzbudziłyby one jego zainteresowanie ${ }^{61}$. Uderza zadziwiająca zgodność intuicji fenomenologów i Witkacego, nie wydaje się ona przypadkowa i wykracza poza sam fakt zainteresowania cielesnością. Można chyba, bez zbędnej przesady, nazwać Witkacego zapoznanym pionierem badań fenomenologicznych nad ciałem na gruncie polskim.

\footnotetext{
${ }^{58}$ Choć psychika posiada lokalizację w ciele - jest ona jednak rozumiana jako punkt, więc niezgodnie

z ustaleniami Witkiewicza (por. Półtawski 1973: 274). Witkiewicz opowiada się jednoznacznie za przestrzennością świadomości i jej treści (Witkiewicz, Ingarden 2002: 52).

${ }^{59}$ Komentator uznaje, że „,[...] ostateczną przeszkodą w rozwinięciu realistycznej interpretacji bezpośredniego doświadczenia rzeczywistości okazuje się [...] dla Husserla pierwotna, tradycyjna koncepcja doświadczenia zmysłowego: gdyż ona to właśnie pozwoliła mu na uznanie świadomości za zasadniczo i wyłącznie dominującą i na wyłączenie naszego realnego, dynamicznego kontaktu ze światem - nawet wtedy, kiedy kontakt ten sam w sposób bardzo wnikliwy opisał” (Półtawski 1973: 305).

${ }^{60}$ Husserl wyróżnia dwa główne elementy świata: „fizyczną przyrodę” i „ducha” - między nimi stawia „,iało” i „duszę” człowieka. Ostateczną realnością, podstawą bytową okazuje się niezależny i samostanowiący „duch” (Husserl 1974: 399, 415-424).

${ }^{61}$ Należy w tym miejscu wspomnieć o fenomenologii Michela Henry’ego (2007, 2012), którego poglądy wydają się najbardziej zbliżone do Witkiewicza w związku z naciskiem na bezpośrednie doświadczenie cielesności i przekonanie o jego źródłowym, fundującym wszelki namysł charakterze. Porównanie takie wykraczałoby jednak poza ramy tego opracowania.
} 
Wypada jeszcze na zakończenie podrozdziału zapytać, czy Witkacy nie docenia roli umysłu, czy nie zauważa, że to właśnie dzięki świadomości jesteśmy tym, czym jesteśmy: konkretną osobowością, nie tylko czuciami cielesnymi, ale osobowością z wszystkimi jej pragnieniami, myślami, radością i smutkiem? Tak nie jest. Witkacy akcentuje raczej ciało w obliczu - jak mu się wydaje - zapoznania go. Ciało i „mojość” z niego płynąca jest bardziej pierwotna i podstawowa dla bytu, ale nie wyklucza zaistnienia wyższych funkcji psychicznych $^{62}$. W Appendixie A do Traktatu o Bycie... znaleźć można interesujący fragment, w którym Witkacy odpowiada na powyższe pytania.

Witkacy zdaje się wyróżniać u człowieka warstwy, które różnią się stopniem, poczuciem „mojości”. Mamy więc „sprzęgnię organizmu” (to kości, mięśnie i ścięgna) ,,[...] noszącą organy istotniejsze, jak płuca, serce, system trawienia itd., które w stosunku do systemu centralnego [...] odznaczają się najmniejszą stosunkowo mojością” (Witkiewicz, w druku). „System centralny” to oczywiście umysł (mózg) i to on jest źródłem najbardziej intensywnego poczucia ,ja”, które jednak, jak dalej będzie się można przekonać, stanowi przyczynę zafałszowania realności. Witkacy mówi o umyśle jako o

[...] nie czującym siebie jako takiego, jako „cielesnego flaka”, organie będącym najistotniejszym siedliskiem osobowości, tzn. miejscem gdzie ona bez substratu cielesnego jako takiego najbardziej skondensowanie jest w postaci „mojości” zasiana w wyobrażeniach, obrazach pamięciowych i «myślach» i skąd promieniuje jako moment niesamodzielny) na resztę ciała swoją mojość: dlatego to głowa jako mojość jest najbardziej intensywna [...] (Witkiewicz, w druku).

Z powyższego fragmentu nie należy jednak wyciągać wniosku, że Witkacy przyznaje umysłowi istnienie bezcielesne; raczej ma na myśli to, że ze względu na jego „siłę” wpływu na nas jako organizm i nasze przeżywanie samych siebie skłania się do nadania mu zbytniej wagi. To jednak ciało - samoczujące się poprzez ból czy napięcie mięśni - okazuje się tym, co najistotniejsze. Umysł, choć wydaje się, że dominuje, jawi się jedynie jako pewny - wcale niekonieczny $\mathrm{w}$ tak rozbudowanym kształcie - dodatek do tej pierwotnej cielesności, która obdarzona jest „mojością” odczuwaną bardziej bezpośrednio niż poprzez obrazy wzrokowe i myśli. Witkacy odrzuca więc z pewnością Kartezjańskie Cogito lub, bardziej precyzyjnie mówiąc, zauważa niewystarczalność klasycznej formuły. Rozwinięta przez niego mogłaby ona brzmieć: „Myślę... i czuję swoje ciało, więc jestem” (Michalski 2005).

\footnotetext{
${ }^{62}$ Dziś filozof umysłu mógłby powiedzieć, że jego stanowisko to w tym wypadku słaba odmiana emergencji oparta na panprotopsychizmie. Witkiewicz wyraźnie łączy stopień organizacji organizmu ze stopniem rozwoju psychiki (Witkiewicz 2002c: 96, 104, 192).
} 


\section{5. ,Zamykanie oczu”, czyli ,,doświadczenie metafizyczne” Witkiewicza}

Filozof monadystyczno-cielesny powinien być od urodzenia ślepy i dotykać tylko ciat i przedmiotów, i zagtębiać się w swoje czucia bebechowe.

Witkiewicz, żeby zobrazować czy też uwiarygodnić w jakiś sposób proponowane przez siebie rozwiązania, prezentuje opis procedury „doświadczenia metafizycznego”, które każdy może przeprowadzić na sobie samym. Jest ono niezmiernie proste, wystarczy bowiem zamknąć oczy i skupić się na doznaniach wewnętrznych. Brzmi to niewinnie, ale dla Witkacego ma głębokie, nietrywialne znaczenie: „Trzeba tylko zamknąć oczy (to mój wynalazek), by nie obserwować ciała z wyżyn głowy jako jednego z przedmiotów mających twarz, by "zobaczyć» tę kardynalną i tak rzadko braną pod uwagę różnicę [...]” (Witkiewicz 1980: 93). Zamknięcie oczu to dokonanie swoistego wczucia w podstawową ontologicznie sytuację podmiotu - to dotarcie do najbardziej pierwotnego „substratu” - nas samych jako ożywionego ciała, posiadającego granice i czującego swoje wnętrze i świat zewnętrzny. Wtedy to przekonuję się, że „Ja jestem swoim ciałem [...]” (Witkiewicz 1979: 153). O tym traktuje cały Appendix A (do Traktatu o Bycie samym w sobie i dla siebie). O zamykaniu oczu jako o źródle poznania istotnego stanu rzeczy w (BDŚ).

Witkacy pisze, iż „Najlepszym dowodem za ważnością ciała [...] jest doświadczenie

z «zamykaniem oczu» - doświadczenie niezmiernie proste polegające na zamknięciu oczu, "wsłuchiwaniu się» [...] w nurt cielesny stawania się w nas [...]” (Witkiewicz, w druku). Szczególnie zależy Witkacemu na wyłączeniu zmysłu wzroku - twierdzi on, iż właśnie wzrok

[...] sfałszował jako taki, a do tego przez umieszczenie w głowie jako w tzw. popularnie „siedlisku myśli” jego wypadowych organów, całą „teorię poznania” i doprowadził do zapoznania istotności ciała w całokształcie elementów, formujących momenty niesamodzielne i względnie niesamodzielne tego, co nazwaliśmy Bytem samym dla siebie (BDŚ) [...] (Witkiewicz, w druku).

Świat jawić ma się pierwotnie i „bardziej adekwatnie” właśnie poprzez ciało, wzrokowe postrzeganie świata jest czymś wtórnym i fałszywie, według Witkacego, odwraca naszą uwagę od ciała. Postrzegamy rzeczywistość wokół nas, ale równocześnie zatracamy zdolność odczuwania cielesnej „mojości”. Można to jednak zmienić i choć na chwilę powrócić do stanu „naturalnego”: „Z zamkniętymi oczami zredukowani jesteśmy do naszego koniecznego egzystencjalnego "substratu» do czegoś jakościowo nie różniącego się od tego w stosunku do nas rudymentu czuć osobowych [...], jakim jest pewno samo dla siebie najprostsze ze znanych nam (IPN)" ${ }^{63}$ (Witkiewicz, w druku). Takie

\footnotetext{
${ }^{63}$ (IP) to symbol oznaczający Istnienie Poszczególne (monadę), (N) sygnalizuje liczbę mnogą.
} 
„wczucie się” w samego siebie pozwala więc równocześnie na specjalny wgląd w stan pierwotny bytu. Według Witkacego możemy wtedy „zasmakować” samopoczucia dużo prostszych od nas organizmów (monad niższego niż my rzędu). Zamykamy oczy, staramy się nie myśleć, jednocześnie pobudzając ciało np. poprzez napinanie mięśni - prowadzi to do zatracenia codziennego poczucia świata fundowanego na doznaniach wzrokowych i myśleniu o percypowanych obrazach. Jak twierdzi Witkiewicz: ,Jest to świetny eksperyment dla ontologicznych idealistów [...], w którym oni nareszcie mogą się zobaczyć, jakimi są w swym najistotniejszym cielesnym podłożu” (Witkiewicz, w druku).

Wzrok jest w końcu oskarżany przez Witkacego o zbrodnię największą wobec prawdy bytu - o idealizm (Witkiewicz 2002a: 53). Tu przywołuje autor Szewców Husserla, który rzekomo zapomina o ciele, znajdując w poznaniu wzrokowym model dla poznania jedynie adekwatnego: poznawania idei przez „,ego transcendentalne”. Jak pisze Witkiewicz:

,Źródło tego stanu rzeczy pozornie introspekcyjnego [...] znajduje się w zmyśle wzroku, mocą którego jesteśmy w stanie patrzeć na nasze własne ciało jako na jeden z przedmiotów wzrokowej przestrzeni, izolując się sztucznie $\mathrm{w}$ niewidzialnej i od środka nieodczuwalnej w przeciwieństwie do brzucha - chyba w chwilach bólu głowy, autorowi nieznanemu - głowie $[\ldots]^{64}$. To ginie do pewnego stopnia przy zamkniętych oczach i pozwala zanalizować stan cielesny, nie „zaplugawiony” wzrokiem, w sposób więcej adekwatny (Witkiewicz, w druku).

Przeniesienie własności percepcji wzrokowej na cały organizm wiedzie do zafałszowania realnego obrazu bytu. Absolutyzujemy sam wzrok oraz obszar, w którym lokalizujemy organ wzroku - głowę, a co za tym idzie, sferę „ducha”, i „zapominamy” o naszej pierwotnej cielesnej konstytucji. Z poziomu, jak barwnie określa to Witkacy, „głowowej latarni” (Witkiewicz 2002: 53) fałszujemy obraz rzeczywistości, postrzegając ciało jako jeszcze jeden przedmiot - moja ręka może być postrzegana tak samo jak stół, na którym ją kładę. Nie wolno jednak zapominać, że „Cały nasz «duch», państwo czystej świadomości” opiera się na „,ciele przeżywanym od środka”, czyli „psychicznej sprzęgni” (Witkiewicz, w druku). Można tylko dodać, że intuicje Witkacego są znów zaskakująco zgodne z rozważaniami Husserla zawartymi już w Medytacjach kartezjańskich, gdzie „[...] zmysł wzroku traci swój prymat na rzecz dotyku” (Pokropski 2011: 122). Tak oto jeszcze raz okazuje się, jak bardzo Witkacy staje się bliski zagorzale przez niego krytykowanym fenomenologom.

\footnotetext{
${ }^{64}$ Można tylko pozazdrościć Witkacemu braku tej - tak częstej - przypadłości.
} 


\section{Zamiast podsumowania}

Rozważania o statusie ciała w filozofii Stanisława Ignacego Witkiewicza wymagają jednego ważnego dopowiedzenia. Witkiewicz został w powyższym artykule ukazany wręcz jako prekursor pewnego stylu myślenia, w którym na pierwszy plan wysuwa się ciało. Czytając prace filozoficzne Witkacego, można odnieść wrażenie, że jego poglądy są na wskroś oryginalne; nie jest tak do końca. Impuls do zajęcia się tematyką cielesności znalazł Witkiewicz w pracach przede wszystkim dwóch niemieckich badaczy: Ludwiga Bussego (18621907) i Aloysa Wenzla (1887-1967). Wiadomo o tym z jego korespondencji (Witkiewicz 1978: 94, 2002: 44) , w której te dwa nazwiska przewijają się w sprawozdaniach z lektur z przywołaniem dwóch konkretnych prac (Busse 1903, Wenzl 1933). Wspomniani autorzy nie są postaciami pierwszoplanowy$\mathrm{mi}$, dlatego też inspiracje $\mathrm{w}$ tym wypadku są trudne do odkrycia. Busse był filozofem, wykładał w Tokio, później w Marburgu, był zwolennikiem paralelizmu psychofizycznego. W zbiorach Połączonych Bibliotek WFiS UW, IFiS PAN i PTF znajduje się egzemplarz pracy Bussego z notatkami Witkacego. Aloys Wenzl był przed wojną wykładowcą filozofii i psychologii w Monachium, odsunięty od nauczania przez nazistów, powrócił do pracy w 1946 roku. Był witalistą, interesował się filozofią przyrody, próbował pogodzić metafizykę Arystotelesa ze współczesną fizyką, zajmował się ponadto parapsychologią. Od razu trzeba też zaznaczyć, że nie ma mowy o kopiowaniu pomysłów, a raczej o wyznaczeniu kierunku poszukiwań, tym bardziej że sam Witkiewicz do ustaleń przywołanych autorów odnosił się raczej krytycznie (Witkiewicz 1979: 145, 2002b: 45). Na tych uwagach należy poprzestać, gdyż szczegółowe porównanie filozofii Witkiewicza $\mathrm{z}$ ideami zawartymi w pracach wspomnianych wyżej autorów przekracza ramy tego opracowania.

\section{Literatura}

Busse, L. 1903. Geist und Körper, Seele und Leib. Leipzig: Dürr’sche Buchhandlung.

Drwęga, M. 2002. Ciało człowieka. Studium z antropologii filozoficznej. Kraków: Księgarnia Akademicka.

Freeman, A., red. 2006. Consciousness and Its Place in Nature: Does physicalism entail panpsychism? Imprint Academic: Exeter, Charlottesville.

Gut, P. 2004. Leibniz. Myśl filozoficzna w XVII wieku. Wrocław: Wydawnictwo Uniwersytetu Wrocławskiego.

Henry M. 2007. O fenomenologii, przeł. M. Drwęga. Warszawa: Wydawnictwo IFiS PAN.

Henry M. 2012. Wcielenie. Filozofia ciała, przeł. M. Frankiewicz i D Adamski, Kraków: Homini.

Husserl, E. 1974. Idee czystej fenomenologii i fenomenologicznej filozofii: księga druga, przeł. D. Gierulanka. Warszawa: Państwowe Wydawnictwo Naukowe. 
Husserl, E. 1982. Medytacje kartezjańskie, przeł. A. Wajs. Warszawa: Państwowe Wydawnictwo Naukowe.

Husserl, E. 1991. Ding und Raum. Vorstelungen 1907, Hamburg: Meiner Verlag.

Leibniz, G. W. 1995. Zasady filozofii, czyli monadologia, przeł. S. Cichowicz, J. Domański. Główne pisma metafizyczne: 113-134. Toruń: Wydawnictwo Comer.

Merleau-Ponty, M. 2001. Fenomenologia percepcji, przeł. M. Kowalska i J. Migasiński. Warszawa: Fundacja Aletheia.

Michalski, B. 1979. Polemiki filozoficzne Stanisława Ignacego Witkiewicza. Warszawa: Państwowy Instytut Wydawniczy.

Michalski, B. 2002. Nieznany traktat filozoficzny Stanisława Ignacego Witkiewicza dedykowany Romanowi Ingardenowi. Pamiętnik Literacki, 93(4): 215-220.

Michalski, B. 2005. Witkacego portret nowoczesny - myślę... i czuję swoje ciało, więc jestem. J. Miodek, red. Między teatrem a literatura. Księga ofiarowana Profesorowi Januszowi Deglerowi $w$ 65. rocznice urodzin: 387-396. Wrocław: Towarzystwo Przyjaciół Ossolineum.

Nagel, T. 2012. Mind and Cosmos: Why the Materialist Neo-Darwinian Conception of Nature is Almost Certainly False. New York: Oxford University Press.

Pokropski, M. 2011. Ciało. Od fenomenologii do kognitywistyki. Przegląd FilozoficznoLiteracki, 4 (32): 119-137.

Półtawski, A. 1973. Świat. Spostrzeżenie. Świadomość. Fenomenologiczna koncepcja świadomości a realizm, Warszawa: Państwowe Wydawnictwo Naukowe.

Rosiak, M. 1988. „Biologiczny monadyzm” Stanisława Ignacego Witkiewicza jako próba poprawienia monadologii Leibniza. W. Maciąg, red. Beznadziejność i nadzieja. W kręgu myśli Stanisława Ignacego Witkiewicza: 55-63. Kraków: Wydawnictwo Uniwersytetu Jagiellońskiego.

Strawson, G. 2006. Realistic Monism: Why Physicalism Entails Panpsychism. Journal of Consciousness Studies, 13(10-11): 3-31.

Tarnowski, J. 2001. Stanisława Ignacego Witkiewicza system ontologii ogólnej. A. Czyż, red. Czytanie Witkacego: 19-36. Wydawnictwo Akademii Podlaskiej, Siedlce 2001. Wenzl, A. 1933. Das Leib-Seele-Problem. Leipzig: F. Meiner.

Witkiewicz, S. I. (w druku). Nauki ścisłe a filozofia i inne pisma filozoficzne (1933-1939). Warszawa: Państwowy Instytut Wydawniczy.

Witkiewicz, S. I. 1978. Listy do Hansa Corneliusa. Dialog, 5: 90-95.

Witkiewicz, S. I. 1979. Listy do Hansa Corneliusa. Przegląd Humanistyczny, 6: 137-157.

Witkiewicz, S. I. 1980. Listy do Hansa Corneliusa. Przegląd Humanistyczny, 2: 87-112.

Witkiewicz, S. I. 2002a. Traktat BDŚ, czyli Traktat o Bycie samym w sobie i dla siebie. Pamiętnik Literacki, 93(4): 220-241.

Witkiewicz, S. I. 2002b. „Pojęcia i twierdzenia implikowane przez pojęcie istnienia” $i$ inne pisma filozoficzne (1902-1932) Warszawa: Państwowy Instytut Wydawniczy. 
Witkiewicz, S. I. 2002c. Spór o monadyzm. Dwugłos polemiczny z Janem Leszczyńskim. Warszawa: Państwowy Instytut Wydawniczy.

Witkiewicz, S. I., Ingarden, R. 2002. Korespondencja filozoficzna. Warszawa: Wydawnictwo IFiS PAN, Collegium Civitas Press.

\begin{abstract}
Stanislaw Ignacy Witkiewicz is an author of a specific and original metaphysics of embodiment developed in the late 1930s. As a supporter of realism and opponent of any type of idealism, Witkiewicz found a kind of a "guarantee" of realism in the body. He proposed a "revised" version of Leibniz's monadology, where monads are no longer spiritual beings but psycho-bodily ones. A sense of embodiment became the primary sensation grounding the metaphysical realism of the author of Shoemakers. The article presents the main points of Witkacy's philosophy of the body. The central category of "mineness" is discussed, along with the question of relations between Witkiewicz's findings and classic phenomenological analyses of embodiment proposed by Husserl and Merleau-Ponty.
\end{abstract}

Keywords: Witkacy; body; metaphysics; phenomenology; Husserl; Merleau-Ponty. 